\title{
Chapter 13 \\ Following People, Visiting Places, and Reconstructing Networks. Researching the Spanish Second Generation in Switzerland
}

\author{
Marina Richter and Michael Nollert
}

\subsection{Introduction}

The literature on the second generation suggests that most research focuses on processes and phenomena linked and constrained to the country where the second generation is presently living. Indeed, researchers have hardly looked at the second generation from a transnational perspective (Levitt and Waters 2002). However, the few transnational studies showed clearly that the question of roots and routes needs to be posed in a slightly different way than when analyzing the first generation (Levitt 2009). The second generation did not initiate a transnational network and a cross-border community. Rather, they are born into an environment where social networks extend across national borders and where family life is organized according to a yearly cycle of visits and holidays with the family "back home" (Louie 2006; Wessendorf 2010; King et al. 2011). The connection to their parents' country of origin is strong enough for some people of the second generation even to migrate and reside there. In order to distinguish this sort of migration from the remigration of the first generation, researchers have used the term "roots" migration to underline that it represents a migration back to (imagined) roots (Wessendorf 2007). Many studies focus on the intriguing question of belonging, as the second generation is born in a country and has the option to claim and build a sense of belonging towards the country of birth as well as towards the country of origin of their parents (Somerville 2008; Åkesson 2011). The sense of belonging can even extend not only to the country where the parents were born, but, in cases where the parents themselves were children of migrants, to the country of origin of the ancestors

M. Richter $(\bowtie) \bullet$ M. Nollert

Faculté des lettres, University of Fribourg, Fribourg, Switzerland

e-mail: marina.richter@unifr.ch; michael.nollert@unifr.ch

C. Bolzman et al. (eds.), Situating Children of Migrants across Borders and

Origins, Life Course Research and Social Policies 7,

DOI 10.1007/978-94-024-1141-6_13 
(Gowricharn 2009). ${ }^{1}$ Belonging is a concept that can relate to many things: the abstract notion of a nation, or a concrete group of people such as a family or the population of a village, it further, also points towards various levels: the national, the regional and even the local. Our usage of the concept remains vague because it was our intention to let the respondents define the quality (abstract or concrete) and the level of their sense of belonging. In this sense the concept will become clearer in the various types of transnational networks and belonging discussed later.

Therefore, transnational lives and belonging represent a complex social formation in terms of social structure as well as in terms of spatial organization: for instance, families live apart from each other and organize their relationships such as care work over long distances (Bowlby 2012). The relationships that structure transnational lives and belonging are complex in themselves as they permanently change. Such changes reflect the restructuration of social networks all along the life-courses. Indeed, the life-course perspective suggests to investigate not only single moments in people's lives, but to take into account how lives change and how social relations develop in time along these changes (Elder et al. 2003). In short: Our research does not focus on networks as a structural context of social action, but on the so-called convoys, those permanently changing networks which are relevant sources of support for the individuals, independently of geographical proximity (Kahn and Antonucci 1980a, b).

Networks and personal biographies are thereby not linked in a straightforward way. They are connected, but we cannot predict a type of network that will result from a certain type of biography or vice-versa. Rather, the networks develop along and together with a person's life-course. The typology we develop later (see Table 13.1) shows that there are linkages such as important biographical events that can have an effect on the transnational networks of the second generation. Vice-versa, the loss of networks is also linked intimately to the way a person's life-course develops.

Our approach was based on an analytical division into several elements in order to apprehend the social and spatial dimensions of these transnational lives. By focusing on people, places, and the networks connecting them, we follow current discussions in the field of transnational migration studies (Richter 2014).

First, people are at the core of transnationalism from below (Guarnizo and Smith 1998). They build transnational relations, maintain them over time, and are there-

Table 13.1 Types of second-generation transnationalism

\begin{tabular}{l|l|l|l|l}
\hline & \multicolumn{3}{|l}{} \\
\hline & & Continuity & Disruption & Reconnection \\
\hline \multirow{2}{*}{ Transnational networks } & \multirow{2}{*}{ Existing } & Type 1 & Type 4 & Type 3 \\
\cline { 3 - 4 } & \multirow{2}{*}{ Missing } & & Type 2 & \\
& & & Type 5 & \\
\hline
\end{tabular}

\footnotetext{
${ }^{1}$ The text, and in particular the description of the four phases of data gathering, is based on an earlier account of the empirical design of the research (Richter 2012) published in Forum Qualitative Research.
} 
fore at the origin of transnational social practice. Second, these people do not float in a global space, but need to touch ground from time to time (Ley 2004). An analysis of transnationalism as an everyday phenomenon needs, therefore, to take into account the localities where the social practice that constitutes these relations and communications across borders, takes place. Locality therefore represents, on the one hand, the social context in which migrants and other transnational actors are rooted, and it stands, on the other hand, for the nodes of the networks (Gielis 2009). Some authors have called such places translocal because they are meaningful owing to their connection across national borders (Brickell and Datta 2011; Smith 2011). Third, these localities need to be connected somehow to become translocal. Such connections have been addressed conceptually through the study of networks (Featherstone 2007; Featherstone et al. 2007). Fourth, the spatial formation that is constituted through the networks of people and places and the practices that maintain them have been termed transnational social spaces (Pries 2008; Faist 2009).

Transnational studies confront researchers with a social phenomenon that is complex, because it is, on the one hand, spatially disrupted, and on the other hand, highly connected in social terms. Researchers have developed various approaches to deal with this complexity. One of the earliest and most cited is the notion of multi-sited research that was discussed prominently by Marcus (1995). The idea of following people, things, metaphors, stories, biographies, or conflicts has been used in various studies in the field of transnational migration (Amelina 2010; Sinatti 2011). Nevertheless, some scholars criticize that these research strategies are seldom truly multi-, but rather, double-sited and that it seems impossible to conduct an equally intensive ethnography in multiple sites (Hage 2005). The problem of conducting parallel ethnographies has, for instance, been addressed by Mazzucato (2010: 206) with her "simultaneous matched samples." While being resource-intensive, the advantage of conducting research simultaneously at two sites by two connected groups of researchers provides accounts of simultaneity that cannot be apprehended otherwise. Other researchers, such as Tarrius, have stressed the aspect of movement and created a moving ethnography (Tarrius 2000; Tarrius 2002). This leads also to mobile methods: "[A] mobile ethnography involves travelling with people and things, participating in their continual shift through time, place and relations with others" (Watts and Urry 2008: 867). The "moving territories" Tarrius (2001) evokes, point towards the tensions that lie at the heart of research on transnationalism: the ambivalence between fixing people and places (territories) and their constant movement. All these approaches have in common, that they obtain rich data by a variety of methods.

The research strategy we are presenting here is also a mixed-methods approach that bridges the spatial disruption and grasps the notions of movement and fixity that are always competing in these studies. A comparison with items measuring the characteristics of social networks in quantitative household panel data exemplifies the reasoning behind our approach. Of course, social capital as a resource and social network data have also gained importance in recent years in quantitative research. For instance, the Swiss household panel, includes a variety of items to grasp the extent of a household's network and can be used for analysis of social support (see for instance Bachmann 2014). However, the data are unsuitable for our question for 
several reasons: First, the standardized and predefined approach does not allow to adapt the focus of data collection to our question of networks important for the relationship to Spain instead of networks of support in general. Second, household panels are national data records, they are not apt to address questions of transnational relationships, where the place of residence and mobility patterns of the members of a network are of importance. Thirdly, household panel data do not allow to deepen the understanding of these networks by following their members individually to other countries. Finally, focusing on few networks also enables to hear the stories about their members and understand how the networks developed.

The method was developed in the context of a larger project ${ }^{2}$ on transnational social spaces. The project "Bridging Places Across Borders: Constitution, Maintenance and Meaning of Transnational Social Spaces" examines how people who constitute and maintain such spaces-including migrants of the first and second generation, as well as non-migrants-perceive these spaces and how this emic perception furthers the theoretical discussion around concepts of transnationalism. The subproject on the Spanish second generation living in Switzerland, which provides the illustrative material for the next Sect. 13.2, also addresses the question of the perception of transnational social spaces and asks about specifics related to the second generation, such as the inheritance of the networks from their parents. The notion of inheritance points towards the importance of time and a perspective that takes into account the life course of the second generation. Such a perspective looks at the biographical aspect as interlinked with other lives (as in the network approach) and as situated and contextualized. Selected results further give an impression of how such a research strategy can be useful.

\subsection{The Research Strategy}

The research design ${ }^{3}$ includes various methods and combines them at different sites, resulting in a process of data collection that comprised four phases. The four phases were inspired by the idea of reconstructing the networks of people and places, investigating changes over time, and collecting different kinds of data to approach the question of perception of transnational social spaces. The phases started in Switzerland, were continued in Spain, and ended again in Switzerland. The first phase focused on the personal history of transnational relations. The narrative interviews with 19 second-generation Spaniards suggested a first impression of

\footnotetext{
${ }^{2}$ The project "Bridging Places Across Borders: Maintenance and Meaning of Transnational Social Spaces" was jointly elaborated and conducted by a team of researchers of the Universities of Fribourg (Michael Nollert and Marina Richter) and of Neuchâtel (Janine Dahinden, Yvonne Riaño and Marc Tadorian), in Switzerland. It was funded by the Swiss National Science Foundation (grant \# 100015_124983) and additionally supported by the University of Fribourg.

${ }^{3}$ The research design and the data collection were developed by Marina Richter. Michael Nollert as the co-author was involved in data analysis and interpretation of the results (see also Richter and Nollert 2014).
} 
second-generation transnationalism and allowed the selection of specific cases for further research. We opted for such a narrowing of the sample because it was an easy task to find people of the second generation, but it was difficult to select people according to their transnational lives beforehand, as this is a rather abstract notion and difficult to explain. Furthermore, the transnational lives, and in particular the transnational spaces and how they are perceived, lie at the heart of the research and could therefore not be explained to the interviewees beforehand. The sampling strived at maximum variety with regard to age, gender, and qualification and stopped when a theoretical saturation was achieved (Glaser and Strauss 1967).

Between the first and the second phase of interviews, we selected five cases according to a typology we will explain further. These cases represent the types of second-generation transnationalism we had encountered in the data. The second phase gathered more systematic data about the networks connecting people and sites. The interviews provided, further, the possibility of obtaining the permission to visit family and friends in Spain. The second phase consisted of two visual types of data: ego-centric network maps and geographical maps. The ego-centric network maps (Kahn and Antonucci 1980a, b) were filled out by the respondents themselves and helped to systematize the people of importance for the interviewee's relation to Spain (see, Bernardi 2011, for another example of mixed-methods-semi-structured interviews, network chart, and network grid-in ego-centric network research). The geographical references of the people drawn on the network map (place of residence or places for family reunions, important holidays etc.) were then drawn on the geographical map (for an account of maps in social research, see Röhl and Herbrik 2008). The marked places on the map helped the interviewees to remember other relationships to Spain.

The third phase provided material about people and places that had been central in the interviewees' accounts. Therefore, the phase took place in Spain. Here as well, various methods were used: First, people indicated by the interviewees were contacted and interviewed about how they experienced the relationship over distance and which were for them important places that linked them to the person interviewed in Switzerland. Second, the various places mentioned were then visited and photographed as documentation for the researcher and, further, as material to evoke in a later phase the spatial points of reference of the interviewees' networks. Third, the field trip to Spain replicated to a certain extent the trips the second generation undertakes when they visit family and friends in Spain. Therefore, field notes completed the data collection containing observations about people and places, but also about the fact of leaving a country, moving to another, changing language and habits, etc.

In the fourth and last phase in Switzerland, the interviewees were contacted again for a final interview. By then, the interviewees had already been contacted two times for interviews, and we had had the opportunity to talk to their family and friends. It was about time to "give them something back". This last meeting ensured, therefore, reciprocity. Sometimes it meant bringing something material, such as special food they had asked for; sometimes it meant bringing something symbolic such as photographs of a bar where they had spent many nights during a bohemian 
phase of their lives. Showing the data (field notes and photographs) and giving an account of the interviews conducted in Spain also ensured reciprocity, while, at the same time, it also recalled people and places. On this basis they were encouraged to draw a picture of the formation that bridges the place where they are living and the various places they feel connected to.

In the next section, a more detailed account of the four phases illustrated with material gathered shows how the step-wise approach provided data on the various elements of a transnational space and touched, in the last phase, the spatial question directly.

\subsubsection{Phase 1: Collecting Transnational Biographies}

The first phase asked a broad sample of people of the Spanish second generation in Switzerland about their transnational experiences, in order to select cases for further data collection. We obtained the contacts through associations, the consulate, political parties, personal networks, and a subsequent snowball system. The theoretically saturated sample (Glaser and Strauss 1967) encompassed a maximum variety of cases to cover different transnational experiences.

The interviews with 19 individuals of the second generation collected a variety of transnational biographies. These biographical accounts (Fischer-Rosenthal and Rosenthal 1997; Völter et al. 2005) emphasized the aspect of time in the development of transnational networks and practices. The interviewees were asked to give an account of their relationship with Spain since their childhood. The terms "relationship" and "Spain" were not defined further, in order to leave them open to the interpretation of the interviewees. The interviews were taped and later transcribed verbatim. The beginning of an interview gives an example of the kind of the gathered accounts :

Interviewer: "To start with, think back to your childhood and think of an event or a memory that has to do with Spain or your family."

Farruco: "My first thought, that just crosses my mind, well, that's the trip to Spain every year in the car, because I have three older brothers, so we were the four of us in the car [with my parents], in the car, on four wheels, 20, no it was even longer, it was maybe 36 hours. We just went from Basel across everything to Galicia. And that is my memory as a second generation. We did this, yes definitely, once or twice a year."

Most of the accounts of their early childhood started with memories about their trips to Spain and the holidays they spent with their family there, playing with their cousins and experiencing a world different from their daily environment in Switzerland. The excerpt shows how the interviewee sets the direction of his story:

\footnotetext{
${ }^{4}$ The interviews were conducted in the various dialects spoken in the German-speaking part of Switzerland. Annotations on maps later on are in German. In the course of the data collection and as the relationship between interviewer and interviewees became closer, some interviews were also conducted in Spanish. The excerpts provided here are, therefore, all translated from either SwissGerman dialect or Spanish.
} 
The family (four boys) jammed in a car driving all the way from Switzerland to Galicia (approx. $2000 \mathrm{~km}$ ), at first together with their parents, and later alone. This is the starting point for a story about a continuous relationship with Spain and, therefore, also continuous travelling to Spain and back. The family (parents and brothers) will remain crucial to the various transnational relationships this person maintains presently. The excerpt also shows how memories are a social construct and are framed by social meaning (Halbwachs 1925). The often adventurous childhood-stories of travelling to Spain in summer represent a constant in the narratives of the second generation.

On the basis of these accounts we constructed a typology of second-generation transnationalism. This typology resulted from a comparison of the interviews focusing on the way the second generation maintains linkages to Spain. Through analyzing the modes of inheritance of transnational networks, the ways of appropriation of these networks, and further, the variety of forms of maintaining them, the differences could be grouped into types along the temporal characteristics of the interviews (Richter and Nollert 2014; Richter 2014). This resulted in the following five types:

Type 1-continuity. Through yearly visits to Spain —in the beginning with their parents, later alone-relationships to people and places in Spain develop into a stable and vivid network until the second generation calls this network of relationships their own. Often the interviewees could not give a direct account of this process, as it happened smoothly without being noticed.

Type 2-detachment/disruption. Often in parallel to the detachment from the parents that happens in the teenaged years, the second-generation youth of this type experiences also a detachment from the "parents' family". Sometimes this detachment is a smooth process; sometimes it is coupled with an event in the family, for instance, the death of somebody the youth loved or felt obliged towards. This leads to a rather immediate disruption with the family, as the obligation to go to Spain and meet the family has lost its rationale.

Type 3-reconnection. This type starts with a detachment, and then later experiences a reconnection with the family in Spain. This can be evoked by an event such as a birthday or a wedding celebration that brings the family together and gives the second generation the opportunity to meet family members and establish new relationships. Another possibility for such a reconnection is when an interviewee decides to reside for some time, for instance for the purpose of studies, in Spain and has plenty of time to reconnect to the family under different circumstances than the ones provided by the yearly holidays.

Type 4-a Spain of one's own. Most of the second generation Spaniards living in Switzerland are children of guest workers. When they surpass their parents' educational level and obtain university diplomas - in particular when the diplomas are linked to literature or arts—-some discover a world previously unknown to them. On the basis of their interest for (high) culture such as literature and fine arts, they build a new relationship with Spain that is not based on the social networks of their parents, but on a notion of belonging transmitted through their parents. 
Type 5-being Spanish in Switzerland. For this type, being Spanish is not based on relationships maintained with people in Spain. The daily life is, rather, spent in a context of Spanish family, friends, and associations in Switzerland, which provide a sense of being Spanish without the direct link to the country and people living there.

The following phases concentrated on representatives of the types with transnational networks ( 1,3 , and 4$)$. Two contrasting cases were selected for the "continuity" (1) and for the "reconnection" (3) type. For the type representing "a Spain of one's own" (4) only one person was selected, as it represents a weak type of transnationalism at the margin of the research question. For some cases, the phases represent also phases in their life course. For instance, a person who experienced a reconnection of her/his relationship went before through a phase of disruption, and somebody whose relationship with family and friends in Spain is characterized by continuity might at some point experience a disruption.

\subsubsection{Phase 2: Identifying Important People and Places}

For the second phase the five interviewees selected from the first phase were contacted again to systematize the account they had related. Two instruments were used: ego-centric network maps and geographic maps. Both were accompanied by a semi-structured interview to explain the visual data the interviewees were producing. The interview was taped and later transcribed.

The ego-centric network maps show the individual in the middle as the center of the network. The three concentric circles are used to annotate people who are closest, less close and rather weakly connected to the individual in the center. As a further help, the circles are divided into three sectors or social spheres: family (Familie), friends and leisure (Freunde/Freizeit), and work (Beruf). The interviewees were asked to fill in the people (family, friends and colleagues from work) who are important for their relationship with Spain, regardless of whether these people live in Spain or elsewhere (see, Fig. 13.1).

This network map suggests that most of the respondents had, above all, family relationships connecting them to Spain. The relationships start with their close family, such as parents and siblings, and stretch then further to aunts and cousins and other members of the extended family. But there are also relationships in the areas of work environment and among friends or leisure activities that link them to Spain. Whereas friends and working environment are more often located in Switzerland, the family is usually more concentrated in Spain. In this example, most of the extended family is concentrated in Spain, including the parents and one of the brothers, whereas the two other brothers each live on another continent. This family spans over three continents and four countries.

Whereas the network maps sort the members of the networks, the geographic maps arrange the places. The interviewees marked on the geographical map the 

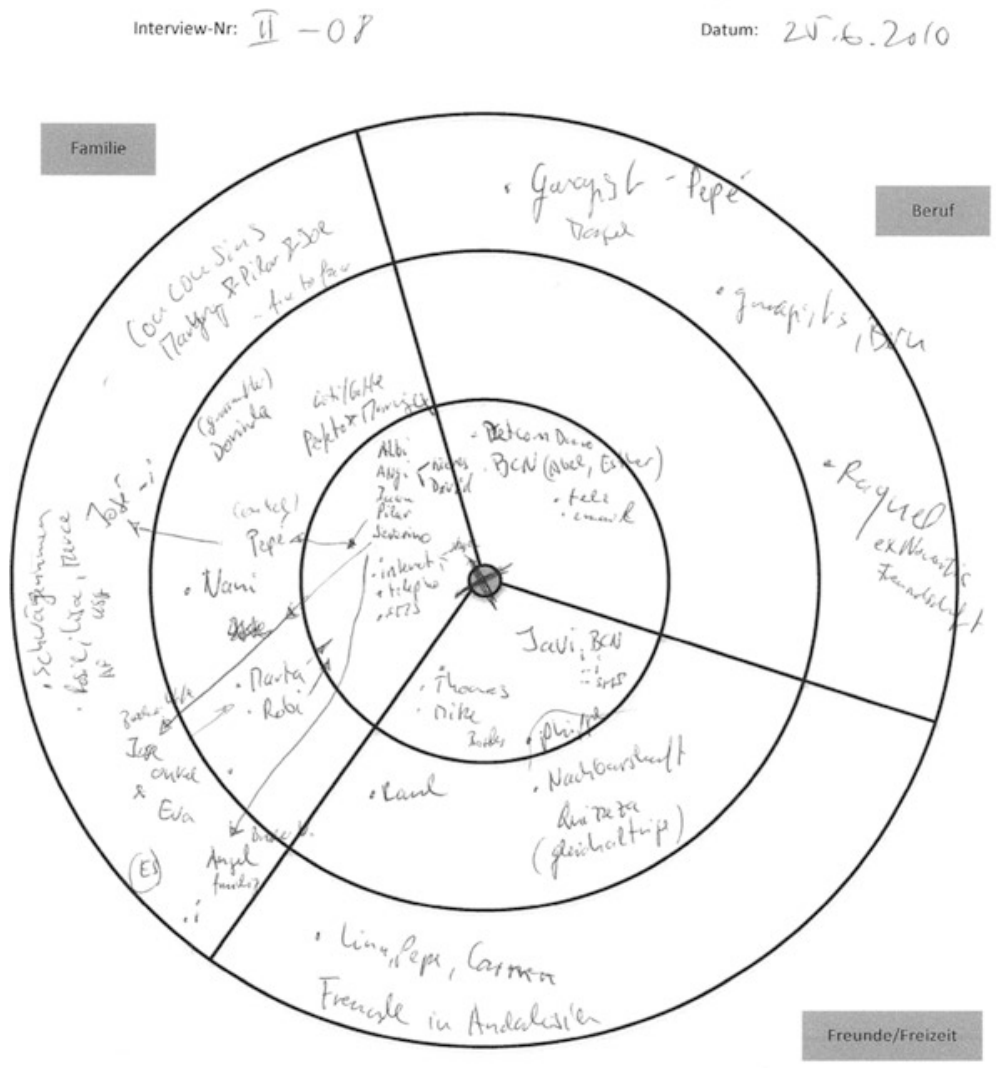

Fig. 13.1 One example of an ego-centric network map

places where the people mentioned in the network map were living. Then, looking at the map helped them to remember other important sites that they had forgotten to talk about (Fig. 13.2). The black crosses on the geographical map represent the places marked according to the people drawn in the network map. As the respondents started talking about the places marked with crosses, they also recalled other sites and regions they had visited during holidays or where they had spent some time living or studying (grey circles). The map helped the interviewees to talk about the places linked to the people in the network map. It also helped them to remember places that were not directly linked to people appearing on the network map but that had an importance of their own. The geographical map (Fig. 13.2) pointed out that asking only about the people in the networks meant that we would have missed important places that connect the second generation through stories and personal experiences to Spain. 


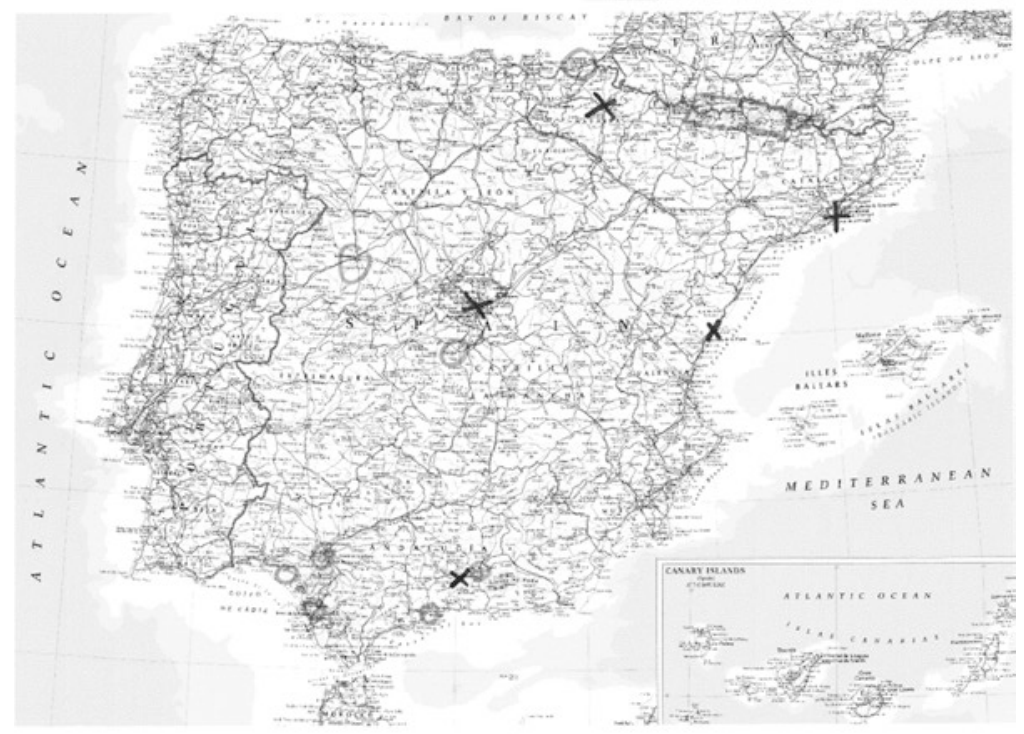

Fig. 13.2 One example of geographical map

\subsubsection{Phase 3: Meeting People and Visiting Places in Spain}

The third phase took place in Spain. The five cases selected for further data collection had contacts in various regions of Spain, but the important people were concentrated in the urban area of Barcelona and rural areas of Galicia (in the northwest of the country). Data collection included mainly two parts, meeting people and visiting places. Visiting the mentioned places resulted in photographs and field notes. The photographs played an important role later in the fourth phase when meeting the interviewees for a last time, and they were also something that we could bring back for them from the field trip. The photographs represented places that had already emerged in the accounts of the second generation (Fig. 13.3), or they could also represent places pointed out by the family members and friends in Spain (Fig. 13.4).

The first photograph shows a narrow street in the old part of the city center of Barcelona, where one of the respondents lived when she was attending a course at the University of Barcelona. The second picture shows a beach on the coast of Galicia. This beach had not been mentioned by the interviewee himself, but had been pointed out later by his cousin after the interview we conducted with her. The family holds gatherings there when everybody meets during the long summer holidays in the village. The two photographs show the variety of places that were named as important points of reference for the relationship the respondents had with Spain and with their family and friends there: urban and rural sites highly frequented or 
Fig. 13.3 Carrer Sant Pere Mitja (Barcelona)

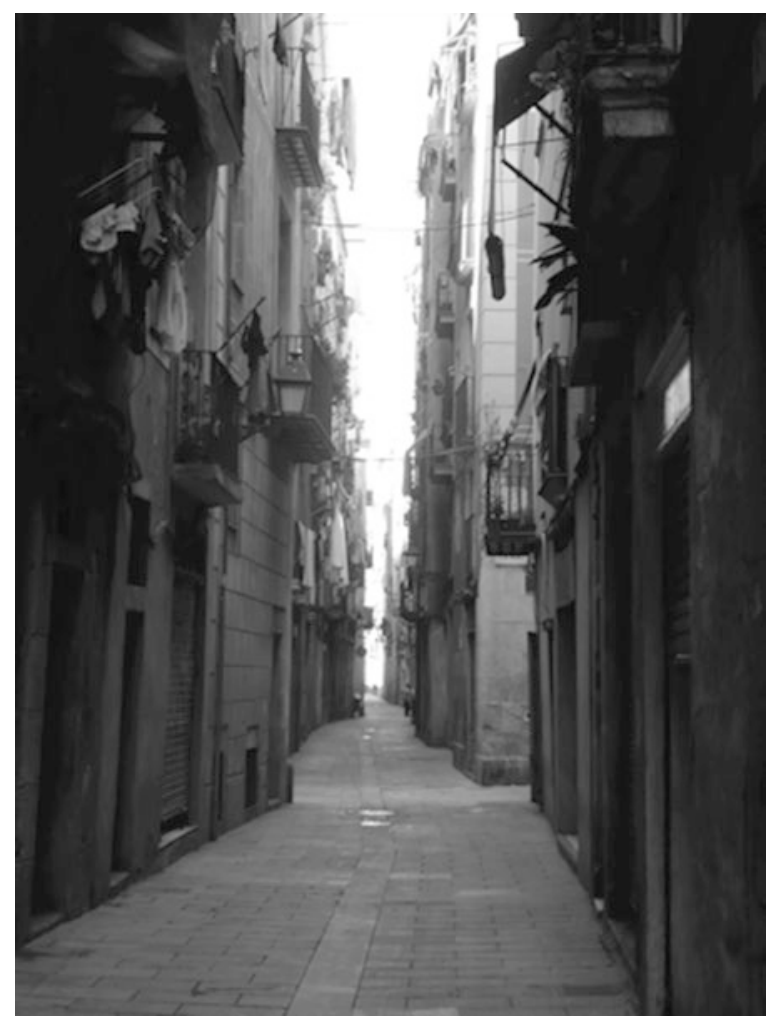

deserted as both examples. They represent a place that links to personal memory or a "museum of memory" (Richter 2011: 225): places that represent emotional moments in a person's life and as places they make these memories a living experience, one can walk them and remember.

The sites shown in the pictures and the people met were sometimes directly linked, such as in the second case. Sometimes, the pictures and the interviews enhanced each other, when places represented elements of a shared memory. These places have become meaningful for a social group, such as the family in this context, and can therefore become part of a collective or shared memory (Halbwachs 1925). In the example of the street in the old part of Barcelona, it became a topic of the interview we conducted with the aunts of the respondent who had been living in this street. The aunts were asked what places made them think of their niece or what places are connected in their memory with their niece. The following excerpt shows how they debated the places that are important and in the end recalled the same place the niece back in Switzerland had been talking about: the Carrer Sant Pere Mitja. 


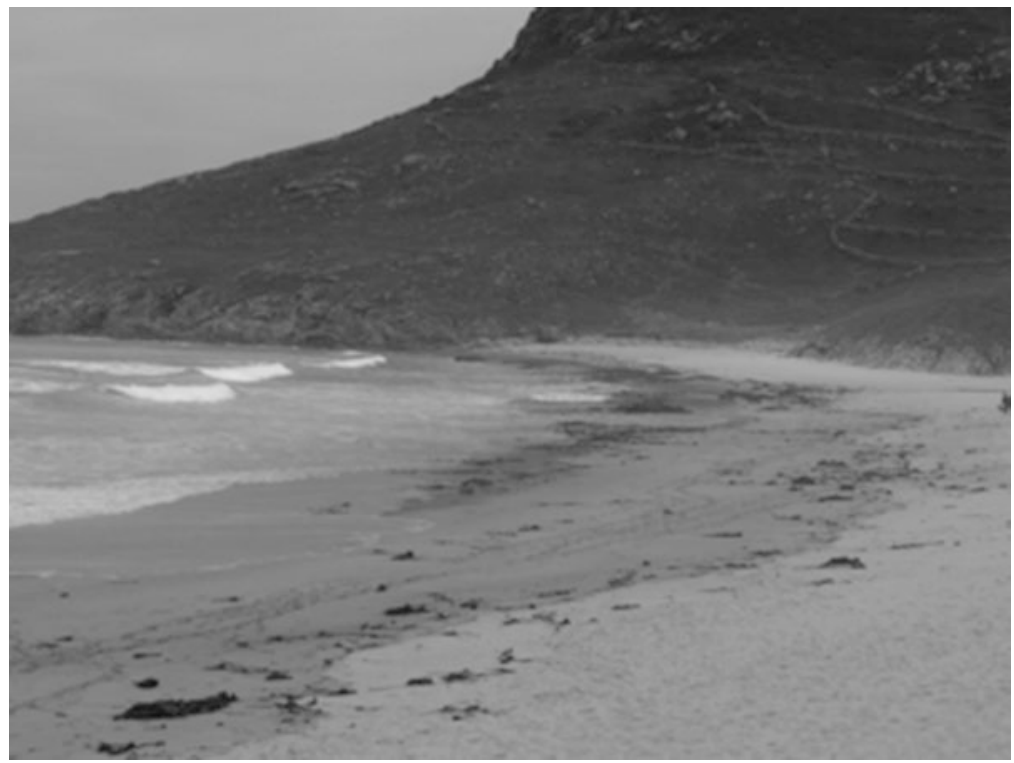

Fig. 13.4 Beach on the coast of Galicia

Interviewer: "We have been talking about sites in Switzerland where you visited. Are there any sites in Barcelona that have to do with Teresa [their niece in Switzerland]?"

Aunt 1: "Well, what I thought was funny, when she came the second time with her partner, they went to live in the old part of the city, where I had given my first classes. And, well, I like the old part very much. Now, when I pass by there, that makes me think of her. But that is rather recent."

Aunt 2: "You used to take her to the zoo."

Aunt 1: "Well, but that was when she was very young. But when she spent a whole year here, then we used to go to the Palau de la Musica [concert hall]. But yes, it is mainly this little, tiny flat they had in the old part of the city that makes me remember her when I pass by there."

\subsubsection{Phase 4: Drawing Transnational Social Spaces}

Back in Switzerland, the fourth phase consisted of a last interview with the five respondents. As this was already the third interview, the setting was much less formal, and it started with us telling them about the experiences in Spain, whom we had talked to and where we had been. Thereby, we could inverse the relationship of the interviewer who asks questions and the respondent who answers by telling our experience. The five people selected for the in-depth analysis of their networks cooperated until the end. When selecting the cases we had also taken into account their willingness to cooperate further and we were always clear about the empirical steps 
Fig. 13.5 Drawing spaces: the time warp

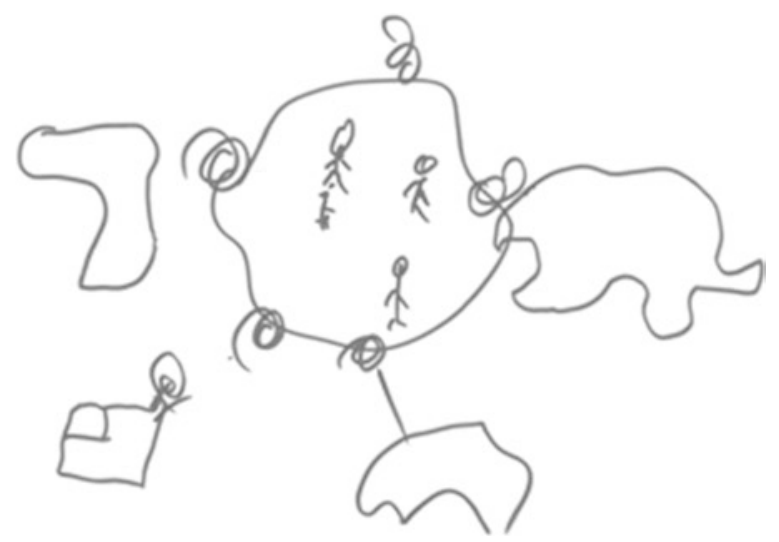

we had planned. Taking the role of the narrator also provided the opportunity to show the material and let them comment on the photographs and the stories we had collected to complete the picture further. Recalling places, people, and memories provided a basis for asking about their perceptions of transnational spaces.

The photographs helped the interviewees to remember stories and memories they had not told us before. For instance, the beach of Galicia (shown in Fig. 13.4) reminded the interviewee of the fact that he used to go there with his uncle and his cousin to search for crabs. Later, the aunt would cook them for dinner. As this story shows, the pictures and the accounts of the field trip in Spain helped to recall this imagined space that in migration research is called the transnational social space. Asking the interviewees how they perceived this space spared using the word or explaining the notion. Therefore, we drew a first sketch of Switzerland and Spain while talking about people here and there, about places visited, and about connections heard about. The drawing showed in a very simple way what we usually imagine when we talk about transnational social spaces: countries and places within, all connected through social networks. By drawing, we invited them to take a pen and draw their impression of how these connections and social formations could be conceptualized.

The drawing (Fig. 13.5) shows the formation created by the transnational networks that link a family on various continents. In contrast to the geographical mapping we had sketched, the person who made this drawing completely changed the order of things. He placed the family in the core circle. Through their linkages, their practices such as calling, communicating through Skype, sending emails, visiting each other, or sending goods across the whole world to each other, they constituted an entity that holds together what is otherwise spatially disrupted. Because of modern communication and transportation technologies-they are symbolized by the time warp signs that connect instantly continents and countries as in a science fiction film-the distances become irrelevant. Through Skype, they have contacted 
each other in their respective homes before they went there physically. All family members also have enough economic capital to afford flights and visits in person. Further, they pool among the family members various skills and contacts that enable them to organize sophisticated projects, such as finding a tabletop football in Spain and sending it to Australia as a present from one of the family members in Switzerland to a friend in Australia (Richter 2010).

\subsection{Major Results}

In the course of the subproject on the second generation four major findings emerged. First, we were able to derive a typology of second-generation transnationalism that takes into account how the second generation develops transnational relationships over time. These types are based on how the second generation keeps, maintains, breaks and reconnects the transnational social capital they inherited from their parents. This notion of inheritance constitutes an important difference compared to first-generation transnationalism. In contrast to the first-generation residents who maintain ties transnationally that they had created before in the context of daily face-to-face contact in Spain, the second-generation inherits not only the ties-which applies to every child inheriting the familial ties from his or her parents-but has to appropriate and maintain them over distance without the initial close rapport (Richter 2014). The distance between Spain and Switzerland does not impede or hinder the appropriation and maintenance of the transnational ties, but it highlights that the inheritance of social networks creates a potentiality of social capital that requires an investment to be activated. Furthermore, an interest in the family in Spain mostly turns into an interest in places and in other relationships such as friends and, more rarely, work relationships.

Secondly, we reworked the typology on second-generation transnationalism and differentiated between transnational networks and transcultural belonging. This allowed us to differentiate what Levitt and Glick Schiller (2004) had termed transnationalism as ways of being and ways of belonging. The analysis of the interplays between networks and forms of belonging across borders suggested that transnational networks and transcultural belonging do not simply go hand in hand (Richter and Nollert 2014). The typology presented earlier was therefore adapted and differentiated to comprise the following types: (1) continuity of transnational networks and transcultural belonging - networks, as well as feelings of belonging, were continuously maintained since childhood; (2) reconnection of transnational networks and revitalization of transcultural belonging - this type revitalized the transcultural feeling of belonging after also reconnecting the transnational networks; (3) belonging without transnational ties-for this type (in the earlier typology represented by the "Spain of one's own") the feeling of belonging is not linked to transnational networks, in particular not to the networks inherited from the parents. Whereas 
transcultural belonging is rooted in the familial origin, eventual networks are constituted later and outside the family; (4) belonging beyond transnational ties- the type called in the earlier typology "being Spanish in Switzerland"-represents an interesting case of expressing a feeling of belonging to the Spanish community specifically in Switzerland but not to Spain or to family and friends in Spain; and (5) rupture of networks and detachment from belonging - the last type, then, breaks with the networks as well as with the feelings of belonging. These interviewees clearly stated that they defined themselves as Swiss and not as belonging to both countries at once.

The typology shows that with respect to transnationalism, the ways of being and of belonging are linked, but not in a simple way. For the second generation it is again the inheritance of their parents' networks and the way they are able to appropriate and later maintain the social ties that are crucial for their ways of belonging transculturally. The connection between both forms of transnationalism cannot be expressed in a direct correlation; there are cases where the transnational links are missing, but a transcultural belonging (based not on family links, but related, for instance, to culture in the sense of arts) is still expressed. Other cases connect both or are missing both. We could not find any case of existing transnational links without transcultural belonging. We think this is because of the case we examined: the second generation bases its networks and feelings of belonging, at least at the beginning, on the sense of origin inherited from their parents. Other transnational actors that build their social capital on a shared interest and not on a belief of descent and national/local belonging, such as business people or lifestyle groups, might maintain networks without a sense of belonging.

Third, we relied on the accounts, but also, in particular, on the drawings done by the interviewees to apprehend their notion of the spatial and social formation that spans their places of living and working and their family' and friends' places in Spain. A first point to note is that the spatial accounts evoked very concrete places in Spain, such as the street where the grandparents live, or the little stream where they used to play with other kids from the village when they were younger. Although we started the interviews by asking them about their relationship with Spain, it became clear that the places they always talked about were connected to stories in their biography. This might in itself not be a surprise, but it is an important point to consider when planning the data collection and when designing the instruments. Talking about Spain usually evoked a very abstract account whereas the concrete places were tied to emotional moments and memories along their biographies.

Finally, the research also underlines the importance of researching a social phenomenon that is based on movement by "moving methods" (Tarrius 2001; Watts and Urry 2008). Even though the research question did not focus on movement, travelling between Switzerland and Spain plays an important part in maintaining the transnational ties. Therefore, movement lies in an implicit way at the very heart of the study, though it remains restricted to a few times per year and to roughly the same trajectories every time. The notion of the moving researcher seemed particu- 
larly important in our study. The travelling of the researcher that was part of phase 3 not only represented a method of gathering data, but also served as a common experience between the interviewees and the researcher. This common experience was the basis for the last phase to evoke notions of places, people, and the movement from one place to another as a way of connecting the nodes of these transnational networks.

Acknowledgments The project was funded by the Swiss National Science Foundation (grant \# 100015_124983). Additional funding for the field work was provided by the University of Fribourg. This paper benefited from the support of the Swiss National Centre of Competence in Research LIVES-Overcoming Vulnerability: Life Course Perspectives, which is financed by the Swiss National Science Foundation (Grant number: 51NF40-160590).

\section{References}

Åkesson, L. (2011). Multicultural ideology and transnational family ties among descendants of Cape Verdeans in Sweden. Journal of Ethnic and Migration Studies, 37(2), 217-235.

Amelina, A. (2010). Searching for an appropriate research strategy on transnational migration. The logic of multi-sited research and the advantage of the cultural interferences approach. Forum Qualitative Sozialforschung/Forum Qualitative Social Research, 11(1), Art. 17.

Bachmann, N. (2014). Soziale Ressourcen als Gesundheitsschutz: Wirkungsweise und Verbreitung in der Schweizer Bevölkerung und in Europa (Obsan Dossier 27). Neuchâtel: Schweizerisches Gesundheitsobservatorium.

Bernardi, L. (2011). A mixed-methods social network study design for research on transnational families. Journal of Marriage and Family, 73(4), 788-803.

Bowlby, S. (2012). Recognizing the time-space dimensions of care: Caringscapes and carescapes. Environment and Planning A, 44(9), 2101-2118.

Brickell, K., \& Datta, A. (2011). Translocal geographies: Spaces, places, connections. Farnham/ Burlington: Ashgate.

Elder, G. H., Johnson, M. K., \& Crosnoe, R. (2003). The emergence and development of life course theory. In J. T. Mortimer \& M. J. Shanahan (Eds.), Handbook of the life course (pp. 3-19). Boston: Springer US.

Faist, T. (2009). Making and remaking the transnational: Of boundaries, social spaces and social mechanisms. Spectrum: Journal of Global Studies, 1(2), 66-88.

Featherstone, D. (2007). The spatial politics of the past unbound. Transnational networks and the making of political identities. Global Networks, 7(4), 430-452.

Featherstone, D., Phillips, R., \& Waters, J. (2007). Introduction: Spatialities of transnational networks. Global Networks, 7(4), 383-391.

Fischer-Rosenthal, W., \& Rosenthal, G. (1997). Narrationsanalyse biographischer Selbstrepräsentationen. In R. Hitzler \& A. Honer (Eds.), Sozialwissenschaftliche Hermeneutik (pp. 133-164). Opladen: Leske + Budrich.

Gielis, R. (2009). A global sense of migrant places. Towards a place perspective in the study of migrant transnationalism. Global Networks, 9(2), 271-287.

Glaser, B. G., \& Strauss, A. L. (1967). The discovery of grounded theory: Strategies for qualitative research (observations). Piscataway: Aldine Pub. Co..

Gowricharn, R. (2009). Changing forms of transnationalism. Ethnic and Racial Studies, 32(9), $1619-1638$.

Guarnizo, L. E., \& Smith, M. P. (1998). Transnationalism from below. New Brunswick/London: Transaction Publishers. 
Halbwachs, M. (1925). Les cadres sociaux de la mémoire. Paris: PUF Presses Universitaires de France.

Hage, G. (2005). A not so multi-sited ethnography of a not so imagined community. Anthropological Theory, 5(4), 463-477.

Kahn, R. L., \& Antonucci, T. C. (1980a). Convoys over the life course: Attachment, roles, and social support. Life-Span Development and Behavior, 3, 253-286.

Kahn, R. L., \& Antonucci, T. C. (1980b). Social networks in adult life. Network Questionnaire. doi:10.3886/ICPSR09254.

King, R., Christou, A., \& Teerling, J. (2011). "We took a bath with the chickens": Memories of childhood visits to the homeland by second-generation Greek and Greek Cypriot "returnees". Global Networks, 11(1), 1-23.

Levitt, P. (2009). Roots and routes. Understanding the lives of the second generation transnationally. Journal of Ethnic and Migration Studies, 35(7), 1225-1242.

Levitt, P., \& Glick Schiller, N. (2004). Conceptualizing simultaneity. A transnational social field perspective on society. International Migration Review, 38(3), 1002-1039.

Levitt, P., \& Waters, M. C. (2002). The changing face of home. The transnational lives of the second generation. New York: Russell Sage Foundation.

Ley, D. (2004). Transnational spaces and everyday lives. Transactions of the Institute of British Geographers, 29, 151-164.

Louie, V. (2006). Growing up ethnic in transnational worlds. Identities among second-generation Chinese and Dominicans. Identities, 13(3), 262-294.

Marcus, G. E. (1995). Ethnography in/of the world system. The emergence of multi-sited ethnography. Annual Review of Anthropology, 24, 95-117.

Mazzucato, V. (2010). Operationalising transnational migrant networks through a simultaneous matched methodology. In R. Bauböck \& T. Faist (Eds.), Diaspora and transnationalism. Concepts, theories and methods (pp. 205-226). Amsterdam: Amsterdam University Press.

Pries, L. (2008). Die Transnationalisierung der sozialen Welt. Sozialräume jenseits von Nationalgesellschaften. Frankfurt a.M.: Suhrkamp.

Richter, M. (2010). "Pulpo a la gallega"—oder wie man eine transnationale Familie beschreibt. SASP Newsletter, 7, 21-24.

Richter, M. (2011). "A country full of snow": Spanish migrants in Switzerland and their engagement with places, memories, and personal migratory history. Emotion, Space and Society, 4(4), 221-228.

Richter, M. (2012). Researching transnational social spaces. Forum Qualitative Sozialforschung/ Forum Qualitative Social Research, 13(4), Art. 12.

Richter, M. (2014). Vernetzte Second@s. Transnationale Netzwerke der spanischen zweiten Generation. In Passagen (Ed.), Vielfältig alltäglich: Migration und Geschlecht in der Schweiz (pp. 270-291). Zürich: Seismo.

Richter, M., \& Nollert, M. (2014). Spaces of belonging: Transnational networks of the Spanish second generation in Switzerland. Global Networks, 14(4), 458-476.

Röhl, T., \& Herbrik, R. (2008). Mapping the imaginary-maps in fantasy role-playing games. Forum Qualitative Sozialforschung/Forum Qualitative Social Research, 9(3), Art. 25.

Sinatti, G. (2011). "Mobile transmigrants" or "unsettled returnees"? Myth of return and permanent resettlement among Senegalese migrants. Population, Space and Place, 17, 153-166.

Smith, M. P. (2011). Translocality: A critical reflection. In K. Brickell \& A. Datta (Eds.), Translocal geographies: Spaces, places, connections (pp. 181-199). Farnham/Burlington: Ashgate.

Somerville, K. (2008). Transnational belonging among second generation youth: Identity in a globalized world. Journal of Social Sciences, 10, 23-33.

Tarrius, A. (2000). Les nouveaux cosmopolitismes. Mobilités, identités, territoires. Paris: Editions de l'Aube.

Tarrius, A. (2001). Au-delà des États-nations: des sociétés de migrants. Revue Européenne des Migrations Internationales, 17(2), 37-61. 
Tarrius, A. (2002). La mondialisation par le bas : les nouveaux nomades de l'économie souterraine. Paris: Editions Balland.

Völter, B., Dausien, B., Lutz, H., \& Rosenthal, G. (2005). Biographieforschung im Diskurs. Wiesbaden: VS Verlag für Sozialwissenschaften.

Watts, L., \& Urry, J. (2008). Moving methods, travelling times. Environment and Planning D: Society and Space, 26, 860-874.

Wessendorf, S. (2007). "Roots-migrants": Transnationalism and "return" among second-generation Italians in Switzerland. Journal of Ethnic and Migration Studies, 33(7), 1083-1102.

Wessendorf, S. (2010). Local attachments and transnational everyday lives: Second-generation Italians in Switzerland. Global Networks, 10(3), 365-382.

Open Access This chapter is licensed under the terms of the Creative Commons Attribution 4.0 International License (http://creativecommons.org/licenses/by/4.0/), which permits use, sharing, adaptation, distribution and reproduction in any medium or format, as long as you give appropriate credit to the original author(s) and the source, provide a link to the Creative Commons license and indicate if changes were made.

The images or other third party material in this chapter are included in the chapter's Creative Commons license, unless indicated otherwise in a credit line to the material. If material is not included in the chapter's Creative Commons license and your intended use is not permitted by statutory regulation or exceeds the permitted use, you will need to obtain permission directly from the copyright holder.

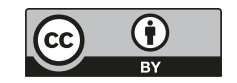

